\title{
Do Agency Costs Really Matter? \\ A Non-linear Approach of Panel Data
}

\author{
Fitriya Fauzi (Corresponding author) \\ The University of Waikato, Waikato Management School, New Zealand \\ Private Bag 3105, Hamilton 3240, New Zealand \\ E-mail: ff21@waikato.ac.nz
}

\begin{abstract}
Stuart Locke
The University of Waikato, Waikato Management School, New Zealand

Private Bag 3105, Hamilton 3240, New Zealand
\end{abstract}

Received: May 8, 2012 Accepted: May 29, 2012 Published: June 1, 2012

doi:10.5296/ajfa.v4i1.1783ＵRL: http://dx.doi.org/10.5296/ajfa.v4i1.1783

\begin{abstract}
This paper investigates the relationship between agency cost, ownership structure and corporate governance mechanisms. Though previous studies of agency problems, corporate governance mechanisms or ownership variables suffer from endogeneity, with respect to the corporate governance it is unclear as to which variables are endogenous and which are exogenous. This study, using the Durbin-Wu-Hausman test for endogeneity, confirms noendogeneity issues should be addressed. Furthermore, addressing the issue of non-linearity, this study confirms that the relationship between agency costs, ownership structures and corporate governance mechanisms are non-linear. Using a balanced panel of $79 \mathrm{New}$ Zealand-listed firms, this study employs a non-linear panel data method using Tobit. Apart from block-holders' ownership, leverage, dividend, non-executive directors and audit committees, managerial ownership, the number of the board size, nomination and remuneration of the committee have significant impact in reducing the agency costs in the context of New Zealand-listed firms. Overall, it can be concluded that corporate governance mechanisms and ownership structures are vital in mitigating agency costs in the New Zealand context.
\end{abstract}

Keywords: Agency cost, managerial ownership, Corporate governance, Non-linear panel Tobit, New Zealand-listed firms

JEL Classification: G34 


\section{Introduction}

In publicly held corporations, the management is usually controlled by non-owner managers. These managers act as agents for the owners, who have hired them to make decisions and to manage the firm for the owners' benefit; that is, to maximise the shareholders' wealth. However, managers also consider their own interests, and the conflict between the goals of the shareholders and those of managers give rise to agency costs. Therefore, corporate governance is necessary to align the interests of shareholders and management.

This conflict of interests has been addressed in a legal way through regulations, such as the Companies Act 1993 in New Zealand (NZ). The Companies Act 1993 is aimed at regulating rules of conduct which firms should comply with, for example: the positions of chief executive and chairman should not be held by the same person; the audit committee should be comprised solely of non-executive directors; there should be a nomination committee for board appointments with a majority of independent directors; there should be a remuneration committee to recommend remuneration packages for directors, the members of which are identified in the annual report. If these rules of conduct are well implemented, they reduce the risk of agency problems within the company. In addition, the Organisation for Economic Co-operation and Development (2004) states that corporate governance involves a set of relationships between a company's management, its board, its shareholders and other stakeholders. The Organisation for Economic Co-operation and Development (OECD) also provides the structure through which the objectives of the company are set, and the means of attaining those objectives and monitoring performance are determined.

Jensen and Meckling (1976) propose two types of agency costs, which are, the agency cost of equity and the agency cost of debt. Agency cost of equity occurs when firms sell shares to outside investors in which the investor pays less for the shares because they expect the firms' performance to change after they buy the shares, and at the end the equity shares issue reduces the market value of corporate assets. To overcome this problem, firms may use debt, as it forces managers to perform effectively, but this also does not come free of charge. Using debt can create agency costs of debt because sophisticated debt-holders will create bond agreements which are costly to negotiate and to enforce.

To mitigate the agency problems, firms can structure the executive compensation shares packages to align managers' interest with stakeholders' interest. Compensation shares contracts give managers incentives to act in the shareholders' best interest, as the shares tie managerial wealth directly to the firm's share price. This encourages managers to maximise the stock price, as their own wealth will increase along with that of the other shareholders'. Lee, Lev and Yeo (2008), in their study of agency problems, found that higher pay dispersion, including managerial equity compensation shares, can mitigate agency problems and ultimately improve a firm's performance. The compensation shares method is the most powerful but most expensive method of overcoming agency problems.

Agency problems also can be reduced by the existence of large investors (block-holders) and dispersed ownership. Block-holders play a significant role in controlling the management by using their influence to suppress underperforming management teams. Dispersed ownership 
affects the controlling power of the management over the firm; the more widely dispersed the ownership, the less the power of the management team. In addition, dividend payment is considered as one of the solutions to mitigate the agency problems. However, larger firms that generate large quantities of free cash flow tend to have severe agency problems, because managers are likely to spend the free cash flow on investment rather than pay it out to shareholders. In addition, there are some other aspects in determining agency problems, which are firm size, firms’ specific characteristics and industry growth rate.

Further, the composition of board directors on the board is a central issue, as is whether such representation on the board is a factor of good governance, or does this create possible conflicts that would be bad for the company. Similarly there are issues of whether there is a significant impact of both owner and non-owner managers' presence in the board on agency costs. Boyle and Ji (2011) report that the average board size in New Zealand-listed firms was about 5.9 directors in 2010. Compared with the US (Ning et al., 2010), the UK (Guest, 2009), and Australia (Kang, Cheng \&Gray., 2007), the board size in New Zealand firms is noticeably smaller, but this reflects the smaller size of NZ firms. Further, Boyle and Ji report that the representation of independent and non-executive component comprised approximately $2 / 3$ and $4 / 5$ respectively of boards in 2010. However, the independent director representation in NZ is lower than elsewhere; for example, independent directors in the US boards were $71.4 \%$ in 2003 (Chhaochharia \& Grinstein, 2007), and in Australia they are 83\% (Kang et al., 2007).

Not all boards are alike. While boards are the main tool of the internal governance mechanism, their efficacy may vary depending on the board characteristics. Therefore, it is necessary to examine whether such corporate governance mechanisms are of importance in affecting agency costs. Furthermore, New Zealand's unique feature of small and medium enterprises and the agricultural industry's domination, which is different from other developed countries, may result in different ownership structures, corporate governance conduct and agency costs. Thus, it is important to investigate the relationship between ownership structure, corporate governance mechanisms and agency costs in the New Zealand context.

The results from this study show the importance of agency costs, ownership structures and corporate governance mechanisms for New Zealand-listed firms, which New Zealand are smaller, compared to other developed countries. So, unquestioning compliance to different codes and principles elsewhere is inappropriate to New Zealand firms. They may have to be customised based on specific needs of the New Zealand context. Furthermore, this study provides recent evidence of which factors contribute in lowering agency costs for New Zealand listed firms.

\section{Literature Review}

There are significant numbers of studies focusing on agency costs across firms and countries which yield mixed results. Some of studies provided theoretical frameworks for understanding why agency problems arise, what the consequences are, and how agency problems and their costs can be reduced. Furthermore, other studies have examined the role of corporate governance mechanisms and ownership structures in mitigating the agency costs. 
The sources of agency problems differ among firms; for example, one firm may have a problem because of their corporate governance structures and another because oftheir ownership structures. For corporate governance structures, there are two conditions must be preserved for an effective governance mechanism; first, the devices used, and second, the mechanismsused to narrow the gap between managers' and shareholders' interests (Denis, Denis \&Sarin, 1997). Furthermore, according to the agency model, Jensen and Meckling (1976) suggested that higher managerial ownership should reduce agency costs because there is a convergence of interests between shareholders and managers as the managers' ownership increases. However, Stulz (1988) suggested that high levels of insider ownership resulted in management entrenchment, thus reducing the firm's value.

Demsetz and Villalonga (2001) suggest that the ownership structures differ across firms because of differences in the circumstances facing firms, particularly in regard to scale of economies, regulations and the environment stability in which they operate. Holderness, Kroszner and Sheehan (2002) show that management ownership in the United States has grown over the last 60 years, and equity ownership can be used to align the interests of management with those of shareholders. However, excessive insider ownership can result in entrenchment of management.

Furthermore, Bhabra (2007) found a significant non-linear relationship between ownership structure and firm performance in New Zealand's listed firms, and suggests that the non-linear relationship is robust to differences in governance structures across market. In 2001, the mean proportion of stock held by the top 20 shareholders in NZ was 73\%, which indicates that NZ's firms are highly concentrated, hence inducing better monitoring and reducing the potential for entrenchment of managers (Hossain, Prevost \&Rao, 2001). Furthermore, from 2007 to 2011, the average mean proportion of stock held by the top 20 shareholders in NZ was 50\%, and this indicates that NZ's firms tend to have moderate ownership concentration. The hypothesis regarding managerial ownership and agency costs is:

\section{$H_{01}$ : The higher the percentage of managerial ownership, the lower the agency costs.}

Reduction of agency costs can also be achieved through block-holders' ownership. The role of block-holders is likely to vary over time periods and countries as a function of the legal system and other regulations. Block-holders may directly influence dividend policy, and managerial ownership may directly influence capital structure policy. However, more complicated interaction effects are possible and perhaps more likely; for example, when there is a large stakeholder, management usually becomes less accountable to shareholders and more accountable to the large controlling stakeholder who will have considerable control over the firm in excess of the cash flow rights. This may reduce the incentive to expropriate funds but not eliminate it.

In 2001, the mean proportion of stock held by the top 20 shareholders in NZ was 73\%, which indicates that NZ's firms are highly concentrated, which consequently induces better monitoring and reduces the potential for entrenchment of managers (Hossain et al., 2001). Similarly, Healy (2001) found that institutional ownership and external block holding in NZ 
counts for $69 \%$, and suggests that higher institutional ownership implies greater monitoring. Furthermore, the average mean proportion of stock held by the block-holders in NZ, during the period 2007 to 2011, was 50\% with maximum value $98.88 \%$, which indicates that the institutional ownership is widely dispersed and hence better monitoring takes place.

Some studies find that block-holders' ownership is likely to reduce agency costs. Hartzell and Starks (2003) report that block-holders' ownership is positively related to the performance sensitivity of managerial compensation; thus, block-holders' ownership monitoring tends to be complementary to incentive compensation systems, mitigating agency problems between both shareholders and managers. On the other hand, Doukas, Kim and Pantzalis (2000) argue that block-holders have neither the time nor expertise to act as effective monitors. Furthermore, Singh and Davison (2003) find no evidence that block-holders' ownership affects agency costs. The hypothesis regarding block-holders' ownership and agency costs is:

$H_{02}$ : The higher the percentage of block-holders' ownership, the lower the agency costs.

Agency costs are also the product of corporate governance conduct and policy. Capital structure and dividend policy are examples of how conflicts of interest between shareholders, managers and debt-holders arise. Firms with higher levels of debt are more closely monitored by debt-holders, and thus can reduce the agency costs (Jensen \& Meckling, 1976). Likewise, Crutchley and Hansen (1989) found a significant impact of leverage in controlling agency costs. Apparently, debt appears to have two positive influences on governance. First, debt-holders take on some function of monitoring (see Begley \& Feltham, 1999; Jensen, 1986). Second, because debt financing reduces the need for sales of shares to raise capital, voting rights remain concentrated in the hands of existing shareholders. As a result, debt makes managers more accountable for consistent performance. However, leverage also brings higher levels of debt-related agency costs and bankruptcy costs. The optimal capital structure should be where the marginal costs of debt equal its marginal benefits. This is the point where the value of the firm is maximised. Nevertheless, issuing debt beyond optimal levels will increase its risk and reduce the value of the company.

Berger, Ofek and Yermack (1997) found evidence that firms with entrenched CEOs tend to have lower levels of debt and boards with few outside directors. Excessive debt can be both positive and negative. It can act as a defense against takeovers (Begley \& Feltham, 1999), while excessive debt may lead to larger risk-taking in order to fund debt servicing. Recent work by Gunasekarage, Locke, Reddy and Scrimgeour (2006) reports that New Zealand firms generally have a debt to assets ratio of $48 \%$, which suggests that holders are acting as an external source of management accountability, which should act as a positive influence on firm performance. Friend and Hasbrouck (1988) suggest that higher inside ownership tends to have less debt, because they prefer to use internal financing to avoid the agency problem with debt holders. The hypothesis regarding the leverage and agency costs is:

$H_{03}$ : The use of leverage lowers the agency cost.

Though the agency costs of dividends imply that dividends are worthless in themselves, dividend is still considered as one appropriate method to alleviate the agency problems 
(Rozeff, 1982; Easterbrook, 1984). Dividends reduce the amount of cash available for management to use for purposes other than maximizing firm performance (Jensen, 1986). As a result, dividends can be interpreted as acting as a tool in reducing agency problems. Corporate governance policies that seek consistent dividend discipline may be developed to avoid disciplining action by shareholders (Myers, 2000). Setia-Atmaja (2010) found a relationship between board independence, dividends, and countries with strong legal shareholder protection; in particular, Setia-Atmaja found that a higher proportion of independent directors are likely to influence a firm's dividend policy and as a result complementary governance mechanisms.

Easterbrook (1984) suggests that dividends may keep firms in the capital market, where monitoring of managers is available at lower costs, and any dividend policy should be designed to minimise the agency costs. Similarly, La Porta, Lopez-de-Silanes, Shleifer and Vishny (2000) affirm that dividend payments play a basic role in limiting insider expropriation because dividends reduce the free cash flow that might be used for under-investment projects. However, the use of dividends is not costless, in that the dividend payment increases the chance of external equity financing which involve having substantial floatation costs to be paid (Crutchley\& Hansen, 1989).In addition, dividend payments do not carry the same legally binding obligation to make payments as debt, making them a less efficient means of forcing managers to pay out cash-flows. In New Zealand, the effect of dividend policy can be directly used as a mechanism to monitor managers' behaviour (Gunasekarageet al, 2006). Furthermore, Crutchley and Hansen find significant impact of dividend in controlling agency costs. The hypothesis regarding the dividend and agency costs is:

$H_{04}$ : The dividend payment lowers the agency costs.

Corporate governance mechanisms, such as the number of directors on the board, the number of non-executives on the board, the presence of audit, nomination, and remuneration committee on the board, play significant roles in mitigating agency costs. According to Lipton and Lorsch (1992) that the board size, as well as the number of directors, is important because the corporate productivity will decline with a large number of board directors. When board size is large, it is difficult to harmonise the conflicts among directors, which leads to not only principal-principal costs but also principal-agent costs. Yermack (1996) and Eisendberg, Sundgren, and Wells (1998) find a negative relationship between board size and firm performance. Larger boards are likely to have higher coordination costs, which reduce their ability to effectively monitor management, hence increase agency costs. The hypothesis regarding the board size and agency costs is:

\section{$H_{05}:$ The higher board of directors, the lower the agency costs.}

The positive role of outside directors on company boards with respect to particular discrete tasks has been explored with respect to disciplining poorly performing top management. Numerous studies suggest that non-executive directors have a positive effect and find that boards dominated by non-executive directors are more likely to act in shareholders' best interests, and more independent boards improve performance through better monitoring of 
management (Borokhovich, Parrino, \& Trapani 1996; Hermalin \& Weisbach, 1988). Agrawal and Knoeber (1996), Klein (1998) and Bhagat and Black (2002) find a negative relation between board independence and performance. In contrast, Hermalin and Weisbach (1991) and Mehran (1995) find no relation between board independence and performance. The hypothesis regarding the number of non-executive directors on the board and agency costs is:

$H_{06}$ : The higher the percentage of non-executive directors on the board, the lower the agency costs.

Board members are also part of committees; therefore, it is beneficial to examine various aspects of committees. There are at least three committees, such as audit committee, nomination committee and remuneration committee, and mostly, the remuneration committees are comprised only of independent directors in order to increase their neutrality in decision making. Findings from this study will improve our understanding of linkage between committees and agency problems. Hence, the audit committee and the remuneration committee are of importance to ensure that the financial procedure is carried out well and the directors' are well compensated, hence mitigating the agency problems. Felo, Krishnamurthy and Soliery (2003) empirically examine the relationship between expertise, independence and size of the audit committees and the quality of financial reporting. They find that expertise and size are positively related to financial reporting quality but are not related to the committee's independence. They state that given the prior evidence of a negative relationship between financial reporting quality and cost of capital, firms could improve their reporting quality by appropriately structuring their audit committees, thus reducing their cost of capital.

The presences of audit committees in public corporate entities have a positive effect on reducing agency cost when measured by cost to revenue (Reddy, Locke \& Scrimgeour, 2010).

Furthermore, an effective nomination committee should ensure the appointment of non-executive directors whose interests are aligned with those of the shareholders and reduce the agency problems. The hypotheses regarding the audit, nomination and remuneration of committees and agency costs are:

$H_{07}$ : The presence of the audit committee on the board lowers the agency costs.

$H_{08}$ : The presence of the nomination committee lowers the agency costs.

$H_{09}$ : The presence of the remuneration committee lowers the agency costs.

\section{Methodology}

\subsection{Data}

This study uses data from the annual report of New Zealand-listed firms for the period of 2007-2011 collected from the NZX deep archive. Those firms with any missing observations for any variable in the model during the research period are dropped, and thus a balanced panel data of 79 New Zealand-listed firms were observed from a total of 147 . Though only 79 
firms were included, the sample may do well in capturing aggregate leverage in the country, because the listed firms tend to represent the whole industry in New Zealand.

\subsection{Variables}

Variables are largely adopted from previous studies, thus this study uses two proxies to measure agency costs, which are assets-to-sales ratio, and the interaction of free cash flow and growth prospects as dependent variables. The assets-to-sales ratio measures the efficiency of the management in how they use the firm's assets to generate sales. A high ratio shows that assets are generating significant sales and therefore suggests low agency costs. A low ratio suggests that management is implementing poor decisions, such as under-investment decisions, and therefore indicates high agency cost. Though these measures have some drawbacks, they provide a useful indicator of agency costs (Ang, Cole \& Lin, 2000; Singh \& Davidson, 2003). Furthermore, the interaction of free cash flow and growth prospects are an indicator of how managers in high growth prospects utilise their large free cash flow, and this is considered as lowering agency costs. In contrast, firms having low growth prospects and large free cash flow tend to suffer high agency costs (Doukas, et al., 2000; Jensen, 1986; Opler \& Titman, 1993).

The explanatory variables are managerial ownership, block-holders' ownership, dividend, leverage, firm size, board of directors, non-executive directors, audit committee, nomination committee, and remuneration committee. In addition, the dummy for industries serve as control variables.

Explanatory variables are defined as follows: managerial ownership is measured as the portion of managers holding the firm's equity shares; block-holders' ownership is measured as the portion of large investors (institutional investors) holding the firm's equity shares; dividend is measured as the proportion of dividend paid to the shareholders; leverage is measured as ratio of total debt over total assets; firm size is measured as the log of total assets; board of directors is measured as the total number of directors serving on the board; non-executive directors is measured as the total of non-executive directors out of the total of board directors; audit committee is a dummy variable that takes the value of 1 if a firm has a formal audit committee and zero if otherwise; nomination committee is a dummy variable that takes a value of 1 if a firm has a formal nomination committee and zero if otherwise; remuneration committee is a dummy variable that takes a value of 1 if a firm has a formal remuneration committee and zero if otherwise; and industry dummy is set as dummy variables.

\subsection{Method}

This study uses panel data which allows the unobservable heterogeneity for each observation in the sample to be eliminated and multicollinearity among variables to be alleviated. Maddala and Lahiri (2008) specify problems that might be present in the regression model, such as heteroskedasticity, multicollinearity and endogeneity problems. Those problems cause inconsistency of the Ordinary Least Square (OLS) estimates. 
As can be seen in the Table 2, most cross-correlations for the independent variables are fairly small, thus, giving less cause for concern about the multicollinearity problem. Further, the Breusch-Pagan test for heteroskedasticity results in 7.43 (p-value 0.006), indicating that variances among the explanatory variables are not constant.

Though previous studies of agency problems, corporate governance mechanisms or ownership variables suffer from endogeneity, with respect to the corporate governance it is unclear as to which variables are endogenous and which are exogenous (Whidbee, 1997). This study, using the Durbin-Wu-Hausman test for endogeneity, confirms noendogeneity issues should be addressed. However, most of those previous studies were based in the US, which has different characteristics, different corporate governance practices and different institutional characteristics from New Zealand. Furthermore, a number of studies have found a non-linear relationship between managerial ownership and performance, which under the agency model, indicates managerial entrenchment (McConnell \& Servaes, 1990; Morck, Shleifer, \& Vishny, 1986; Short \& Keasey, 1999). Addressing the issue of non-linearity, this study confirms that the relationship between agency costs, ownership structures and corporate governance mechanisms are non-linear. Results for linear models do not always carry over to non-linear models, and methods used for one type of non-linear model may not be applicable to another type.

The general approaches to non-linear panel models are similar to those for linear models, such as pooled, population-averaged (PA), random effects (RE) and fixed effects models (FE).

Unlike the linear case, pooled estimation in non-linear models leads to inconsistent parameter estimates. The RE model has a different conditional mean than that for pooled and PA models in which RE is multiplicative. Furthermore, if the FE model is appropriate compared to RE, then an FE estimator must be used, but it only works for long panels (Cameron \&Trivedi, 2010).

For short panels, a non-linear model, binary probit and Tobit are more appropriate. This study employs non-linear panel data method using RE Tobit where the dependent variable is a mixture with zero and positive values. Cameron and Trivedi (2010) suggest that the RE panel Tobit model specifies that latent variable $y_{i t}^{*}$ to depend on regressors, an idiosyncratic error, and individual-specific error, and individual-specific error, so

$$
y_{i t}^{*}=x_{i t}^{\prime} \beta+\alpha_{i}+\varepsilon_{i t}
$$

where $\alpha_{i} \sim N\left(0, \sigma_{\alpha}^{2}\right)$ and $\varepsilon_{i t} \sim N\left(0, \sigma_{\varepsilon}^{2}\right)$ and the regressor vector $x_{i t}$ includes an intercept. For left censoring at $L$, and observe the $y_{i t}$ variable, where

$$
y_{i t}=\left\{\begin{array}{c}
y_{i t}^{*} \text { if } y_{i t}^{*}>L \\
L \text { if } y_{i t}^{*} \leq L
\end{array}\right.
$$

Then the regression model is specified as: 


\section{Macrothink}

$A C_{i t}=\beta_{0}+I O W N P S_{i t}+B O W N P S_{i t}+D I V_{i t}+L E V_{i t}+F S_{i t}+B S_{i t}+N E D_{i t}+A u d C_{i t}+N o m C_{i t}+$ $\operatorname{RemC}_{i t}+C V_{i t}+\varepsilon_{i t}$

where:

AC

: Agency costs

IOWNPS : Managerial ownership

BOWNPS : Block-holders’ ownership

DIV : Dividend paid

LEV : Leverage utilise

FS : Firm size

BS : Board of directors on the board

NED : Non-executive directors on the board

AudC : : Audit committee on the board

NomC : Nomination committee on the board

RemC : Remuneration committee on the board

CV : Control variables that are industry dummy

\section{Findings}

Table 1 presents the descriptive statistics, and the mean value of block-holders' ownership is $50.04 \%$, suggesting that the ownership concentration is moderately dispersed in New Zealand-listed firms. The mean value for managerial ownership is $17.86 \%$, suggesting that the managerial ownership in New Zealand is quite high, as other studies classify the managerial ownership $5 \%$ to $20 \%$ as moderate, while below $5 \%$ as low and above $20 \%$ as high managerial ownership. The mean value of leverage is $47.78 \%$, suggesting that New Zealand-listed firms have considerably moderate debt levels compared to US firms' debt levels. The mean average of non-executive directors is $69.14 \%$ or just over two-thirds, suggesting that the majority directors on boards are non-executive directors. 


\section{1) Macrothink}

Table 1. Descriptive statistics

\begin{tabular}{lccccc}
\hline Variable & Obs. & Mean & Std. Dev. & Min & Max \\
\hline Agency Cost & 395 & 0.1241 & 0.5985 & -0.0033 & 4.5963 \\
BOWNPS & 395 & 0.5004 & 0.3254 & 0.0001 & 0.9886 \\
IOWNPS & 395 & 0.1786 & 0.2362 & 0.0001 & 0.9777 \\
Leverage & 395 & 0.4778 & 0.2414 & 0.0100 & 0.9900 \\
Dividend & 395 & 1.6934 & 20.2460 & -100.75 & 381.11 \\
Board Size & 395 & 0.7772 & 0.1187 & 0.3010 & 1.1139 \\
NED & 395 & 0.6914 & 0.1996 & 0.1667 & 1.0000 \\
Audit_Comm & 395 & 0.9114 & 0.2845 & 0.0000 & 1.0000 \\
Nom_Comm & 395 & 0.5266 & 0.4999 & 0.0000 & 1.0000 \\
Rem_Comm & 395 & 0.7646 & 0.4248 & 0.0000 & 1.0000 \\
Firm Size & 395 & 5.5184 & 1.2742 & 2.7945 & 9.7017 \\
Ind_Primary & 395 & 0.1519 & 0.3594 & 0.0000 & 1.0000 \\
Ind_Energy & 395 & 0.0759 & 0.2653 & 0.0000 & 1.0000 \\
Ind_Goods & 395 & 0.1772 & 0.3823 & 0.0000 & 1.0000 \\
Ind_Property & 395 & 0.0633 & 0.2438 & 0.0000 & 1.0000 \\
Ind_Service & 395 & 0.4177 & 0.4938 & 0.0000 & 1.0000 \\
Ind_Investment & 395 & 0.1013 & 0.3021 & 0.0000 & 1.0000 \\
\hline
\end{tabular}


Table 2. Correlation matrix

\begin{tabular}{|c|c|c|c|c|c|c|c|c|c|c|c|}
\hline & $\begin{array}{l}\text { Agenc } \\
y \text { Cost }\end{array}$ & $\begin{array}{c}B O W N P \\
S\end{array}$ & $\begin{array}{c}\text { IOWNP } \\
\quad S\end{array}$ & $\begin{array}{c}\text { Leverag } \\
e\end{array}$ & $\begin{array}{c}\text { Dividen } \\
\quad d\end{array}$ & $\begin{array}{l}\text { Boar } \\
\text { d Size }\end{array}$ & $N E D$ & $\begin{array}{c}\text { Audit_Com } \\
m\end{array}$ & $\begin{array}{c}\text { Nom_Com } \\
m\end{array}$ & $\begin{array}{c}\text { Rem_Com } \\
m\end{array}$ & $\begin{array}{r}\text { Firm } \\
\text { Size }\end{array}$ \\
\hline Agency & 1.000 & & & & & & & & & & \\
\hline \multirow[t]{2}{*}{ Cost } & 0 & & & & & & & & & & \\
\hline & -0.139 & & & & & & & & & & \\
\hline \multirow[t]{2}{*}{ BOWNPS } & 0 & 1.0000 & & & & & & & & & \\
\hline & -0.011 & & & & & & & & & & \\
\hline \multirow[t]{2}{*}{ IOWNPS } & 9 & 0.1902 & 1.0000 & & & & & & & & \\
\hline & 0.028 & & & & & & & & & & \\
\hline \multirow[t]{2}{*}{ Leverage } & 3 & 0.0751 & -0.0805 & 1.0000 & & & & & & & \\
\hline & -0.000 & & & & & & & & & & \\
\hline \multirow[t]{2}{*}{ Dividend } & 1 & -0.0081 & 0.0127 & 0.0930 & 1.0000 & & & & & & \\
\hline & -0.026 & & & & & 1.000 & & & & & \\
\hline \multirow[t]{2}{*}{ Board Size } & 4 & -0.0006 & -0.0256 & 0.0938 & 0.0251 & 0 & & & & & \\
\hline & -0.007 & & & & & 0.135 & 1.000 & & & & \\
\hline$N E D$ & 9 & -0.1201 & -0.1821 & 0.0654 & -0.0198 & 5 & 0 & & & & \\
\hline Audit_Com & 0.035 & & & & & 0.080 & -0.014 & & & & \\
\hline$m$ & 7 & -0.0162 & 0.0803 & -0.0083 & 0.0143 & 6 & 2 & 1.0000 & & & \\
\hline Nom_Com & -0.142 & & & & & 0.232 & 0.075 & & & & \\
\hline$m$ & 2 & 0.0799 & -0.0559 & 0.0127 & 0.0455 & 6 & 7 & 0.3288 & 1.0000 & & \\
\hline Rem_Com & -0.026 & & & & & 0.198 & 0.056 & & & & \\
\hline \multirow[t]{2}{*}{$m$} & 6 & 0.0163 & -0.0835 & 0.0569 & 0.0289 & 6 & 1 & 0.5619 & 0.5853 & 1.0000 & \\
\hline & 0.439 & & & & & 0.380 & -0.038 & & & & 1.000 \\
\hline Firm Size & 3 & -0.1379 & -0.1308 & -0.0282 & -0.0109 & 1 & 5 & 0.1338 & 0.0846 & 0.0449 & 0 \\
\hline
\end{tabular}

Table 2 presents the correlation matrix of all variables in the model. The highest correlation is between agency costs and firm size at 0.43, suggesting larger firms tend to have larger agency costs. Other variables having the highest correlation are the audit committee and remuneration committee at 0.56 , while the nomination committee and remuneration committee are at 0.58, suggesting that firms having an audit committee are also having a remuneration committee, and firms having a nomination committee are also having a remuneration committee. None of the correlations among explanatory variables are above 0.58 , indicating a low likelihood of multicollinearity issues arising in the OLS regressions.

Table 3 presents the regression results. The regression results for linear and non-linear method are considerably different. The difference is caused by the nature of the data itself. If the data is non-linear, and is estimated as linear, thus possibly leading to inefficient estimators and biased standard error, and vice versa. This data in this study is characterised as non-linear data, though all the estimated coefficients in the linear method exhibit a significant result, but they present biased estimated. The result for the non-linear method yields less significant estimated coefficients, but they present true values to represent the data in this study. 
Table 3. Regression results

\begin{tabular}{|c|c|c|}
\hline Variables & REG. 1_Linear-GLS & $\begin{array}{l}\text { REG. 2_Non-Linear } \\
\text { Tobit }\end{array}$ \\
\hline Constant & $\begin{array}{l}1.7401 * * * \\
(0.1822)\end{array}$ & $\begin{array}{l}0.1846 \\
(0.1497)\end{array}$ \\
\hline Managerial Ownership & $\begin{array}{l}-0.9780 * * * \\
(0.1056)\end{array}$ & $\begin{array}{l}-0.1656 * * \\
(0.0772)\end{array}$ \\
\hline Block-holders Ownership & $\begin{array}{l}0.1610 * * * \\
(0.0531)\end{array}$ & $\begin{array}{l}-0.0622 \\
(0.0400)\end{array}$ \\
\hline Leverage & $\begin{array}{l}-0.313^{* * *} \\
(0.0660)\end{array}$ & $\begin{array}{l}-0.0099 \\
(0.0578)\end{array}$ \\
\hline Dividend & $\begin{array}{l}0.0005 \\
(0.0023)\end{array}$ & $\begin{array}{l}-0.0001 \\
(0.0005)\end{array}$ \\
\hline Board Size & $\begin{array}{l}-2.3260 * * * \\
(0.2198)\end{array}$ & $\begin{array}{l}-0.5501 * * * \\
(0.1360)\end{array}$ \\
\hline Non-Executive Directors & $\begin{array}{l}-0.4076 * * * \\
(0.0945)\end{array}$ & $\begin{array}{l}0.0971 \\
(0.0720)\end{array}$ \\
\hline Audit Committee & $\begin{array}{l}-0.0931 * \\
(0.0560)\end{array}$ & $\begin{array}{l}-0.0426 \\
(0.0620)\end{array}$ \\
\hline Nomination Committee & $\begin{array}{l}0.0194 \\
(0.0400)\end{array}$ & $\begin{array}{l}-0.1570 * * * \\
(0.0363)\end{array}$ \\
\hline Remuneration Committee & $\begin{array}{l}0.3122 * * * \\
(0.0461)\end{array}$ & $\begin{array}{l}0.2269 * * * \\
(0.0436)\end{array}$ \\
\hline Firm Size & $\begin{array}{l}0.0951 * * * \\
(0.0130) \\
\end{array}$ & $\begin{array}{l}0.0627 * * * \\
(0.0117)\end{array}$ \\
\hline Groups & 79 & 79 \\
\hline Wald-Chi2 & 254.60 & 86.50 \\
\hline Prob.Chi2 & 0.0000 & 0.0000 \\
\hline
\end{tabular}

Standard errors in parentheses are for coefficients. *sig. at $10 \%$ level, ${ }^{*}$ sig. at $5 \%$ level, and $* * *$ sig. at $1 \%$ level

From non-linear Tobit, the coefficient for managerial ownership is a negative and is significant at 5\% significance level, suggesting higher managerial ownership can reduce the agency costs. De Angelo and De Angelo (1985) argue that high levels of managerial ownership will entrench management and create agency problems; however, the result of this study indicates that managerial ownership in New Zealand firms lowers the agency costs; this may be due to those managers who are also owners trying to maintain good reputation of their firms by minimising conflicts within the company, hence improving firm performance. This result is similar to what Booth, Cornett and Tehranian (2002) posit, that managerial ownership is of importance in monitoring the divergence between managers and stockholders.

The coefficient for board size is a negative and significant at $1 \%$ significance level, suggesting higher board size can reduce agency costs. The evidence suggests that the higher 
the number of board members, the broader the diversity of board members, hence reducing agency costs. In addition, larger boards provide greater monitoring and advice (Adam \& Mehran, 2003; Anderson, Mansi \& Reeb, 2004; Coles, Daniel \& Naveen, 2008). Further, Boyle and Ji (2011) reported that the average board size fell from about $6.6 \%$ directors in 1995 to $5.9 \%$ in 2010, and that this decline is significant at the $1 \%$ level. Therefore, increasing the board size is able to deal with the agency problem by alignment of interests of shareholders and directors and improve firm performance.

The coefficient for the nomination committee is a negative and significant at $1 \%$ significance level, suggesting the presence of a nomination committee as lowering the agency costs. In contrast, the coefficient for the remuneration committee is a positive and significant at $1 \%$ significance level, suggesting the presence of a remuneration committee as increasing the agency costs. The positive relationship between remuneration committee and agency costs is reasonable because of two reasons; first, the majority of the remuneration committee are non-executive directors; second, the remuneration committee probably wants to increase the remuneration packages.

Using a linear model for non-linear data characteristics will yield inefficient and biased estimators. Though the linear Generalised Least Square (GLS) regression yields a more significant coefficient compared with non-linear Tobit, the result for non-linear Tobit is efficient and unbiased. As can be seen in Table 3, the coefficient for block-holders' ownership, leverage, dividend, non-executive directors and audit committee are insignificant in affecting agency costs for this study using non-linear Tobit.

Overall, apart from block-holders' ownership, leverage, dividend, non-executive directors and audit committees; managerial ownership, the number of the board size, the nomination and remuneration committee have significant impact in reducing the agency costs in the context of New Zealand-listed firms. Hence, it can be concluded that corporate governance mechanisms and ownership structures are vital in mitigating agency costs in New Zealand context.

\section{Conclusions}

As an internal mechanism, corporate boards are expected to play a more proactive role in discharging their fiduciary role for minimising agency problems and improving firm performance. This study examines the relationship between agency costs, ownership structure and corporate governance mechanisms. Using a balanced panel of 79 New Zealand-listed firms, this study employs a non-linear panel data method using Tobit. Though block-holders' ownership, leverage, dividend, non-executive directors and audit committee have no impact in mitigating agency costs, managerial ownership, the number of the board members, nomination and remuneration committees are significant in reducing the agency costs in New Zealand-listed firms' context. Overall, the findings from this study indicate that while corporate governance mechanisms and ownership structures have an important implication for agency costs, one can gain a deeper understanding of such relationships by identifying the contingency conditions in which the relationship between corporate governance mechanisms, ownership structures and agency costs may be dependent on each other. 


\section{Limitations}

The findings of this study are restricted to the limitation of the data, which was collected through publicly available data sources such as annual reports and other databases. If there are any problems relating to data disclosures or professional accounting practices, then that would limit the validity of the findings. In addition, the entire population comprises only 147 firms, which is relatively small. Due to data problems, the final set comprised of 5 years' observations for 79 firms. Nonetheless, the size of the sample is limited by the number of firms listed on the New Zealand stock exchange from 2007 to 2011.

\section{References}

Adam, R. B., \&Mehran, H. (2003).Is Corporate Governance Different for Bank Holding Companies? Economic Policy Review - Federal Reserve Bank of New York, 9(1), 123-142.

Agrawal, A., \&Knoeber, C. R. (1996).Firm performance and mechanisms to control agency problems between managers and shareholders.Journal of Financial and Quantitative Analysis, 31, 377-97.http://dx.doi.org/10.2307/2331397

Anderson, R. C., Mansi, S. A., \&Reeb, D. M. (2004).Board Characteristics, Accounting Report Integrity, and Cost of Debt.Journal of Accounting and Economics, 37(3), 315-342.http.//dx.doi.org/10.1016/j.jacceco.2004.01.004

Ang, J., Cole, R., \& Lin, J. (2000).Agency costs and ownership structure.The Journal of Finance, 55(1), 81-106. http.//dx.doi.org/10.1111/0022-1082.00201

Begley, J., \& Feltham, G. (1999). An Empirical Examination of the Relation Between Debt Contracts and Management Incentives. Journal of Accounting and Economics, 1(27), 229-259.

Berger, P. G., Ofek, E., \&Yermack, D. L. (1997).Managerial entrenchment and capital structure decisions. Journal of Finance, 52(4), 1411-1438. http://dx.doi.org/10.2307/2329441

Bhabra, G. S. (2007). Insider ownership and firm-value in New Zealand.Journal of Multinational Financial Management, 17, 142-154. http://dx.doi.org/10.1016/j.mulfin.2006.08.001

Bhagat, S., \& Black, B. (2002).The non-correlation between board independence and long-term firm performance.Journal of Corporation Law, 27(2), 231-273.

Booth, J. R., Cornett, M. M., \&Tehranian, H. (2002).Board of Directors, Ownership, and Regulation.Journal of Banking \& Finance, 26(1), 1973-1995.

Borokhovich, K. A., Parrino, R., \& Trapani, T. (1996).Outside directors and CEO selection.Journal of Financial and Quantitative Analysis, 31(3), 337-355. http://dx.doi.org/10.2307/2331395

Boyle, G., \&Ji, X. (2011). New Zealand corporate boards in transition: Composition, activity and incentives between 1995 and 2010. [Online] Available: http://www.nzfc.ac.nz/archives/2012/papers/updated/14.pdf 
Cameron, A. C., \& Trivedi, P. K. (2010). Microeconometrics using stata (Rev. Ed.). College Station, Texas: Stata Press.

Chhaochharia, V., \& Grinstein, Y. (2007). The changing structure of US corporate boards: 1997-2003. Corporate Governance: An International Review, 15, 1215-1223. http.//dx.doi.org/10.1111/j.1467-8683.2007.00642.x

Coles, J. L., Daniel, N. D., \&Naveen, L. (2008). Boards: Does One Size Fit All? Journal of Financial Economics, 87(2), 329-356.

Crutchley, C, and R. Hansen.(1989). A test of the agency theory of managerial ownership, corporate leverage and corporate dividends.Financial Management, 18, 36-6.

De Angelo, H., \& De Angelo, L. (1985). Managerial ownership of voting rights: A study of public corporations with dual classes of common stock. Journal of Financial Economics, 14(1), 33-69.

Demsetz, H., \&Villalonga, B. (2001).Ownership structure and corporate performance.Journal of Corporate Finance, 7, 209-33.

Denis, D.J., Denis, D.K., \&Sarin, A. (1997).Agency problems, equity ownership, and corporate diversification.Journal of Finance, 52, 135-160.

Doukas, J., Kim, C., \&Pantzalis, C. (2000).Security analysts, agency costs, and company characteristics.Financial Analysts Journal, 56(6), 54-63.

Easterbrook, F. (1984). Two agency cost explanations of dividends. American Economic Re-view, 74, 650-659.

Eisenberg, T., Sundgren, S., \& Wells, M. T. (1998).Large board size and decreasing firm value in small firms. Journal of Financial Economics, 48(1), 35-54. http://dx.doi.org/10.1016/S0304-405X(98)00003-8

Felo, A., Krishnamurthy, S. \&Solieri, S. (2003). Audit committee characteristics and the perceived quality of financial reporting: an empirical analysis.Social Science Electronic Publishing. Retrieved from http://papers.ssrn.com/sol3/papers.cfm?abstract_id=401240

Friend and Hasbrouck, J. (1988).Determinants of capital structure. In Research in Finance (edited by A.H. Chen), Greenwich, CT: JAI Press, 1-19.

Guest, P. (2009). The impact of board size on firm performance: Evidence from the UK. European Journal of Finance, 15, 385-404. http://dx.doi.org/10.1080/13518470802466121

Gunasekarage, A., Locke, S.M., Reddy, K. \&Scrimgeour, F. (2006). Corporate governance practices of large firms in New Zealand and firm performances: An empirical investigation. Paper presented at the 19th Annual Australasian Finance and Banking Conference, 15-19 December, Sydney.

HartzellJ.,\& Starks L. (2003). Institutional Investors and executive compensation.J Finance, 58(6), 2351-2374. http://dx.doi.org/10.1046/j.1540-6261.2003.00608.x 
Healy, J. (2003). Corporate governance \& shareholder value: Challenges facing New Zealand. Palmerton North: Dunmore.

Hermalin, B. E., \&Weisbach, M. S. (1988). The Determinants of Board Composition.RAND Journal of Economics, 19(4), 589-606.

Hermalin, B., \&Weisbach, M. (1991).The effects of board composition and direct incentives on firm performance.Financial Management, 20, 101-12.

Holderness, C. G., Kroszner, R. S., \& Sheehan, D. P. (2002). Were the good old days that good? Changes in managerial stock ownership since the great depression.The Journal of Finance, 54(2), 435 - 469.

Hossain, M., Prevost, A.K., \&Rao, R.P. (2001). Corporate governance in New Zealand: The effect of the 1993 companies act on the relations between board composition and firm performance. Pacific-Basin Finance Journal, 9, 19-145. Retrieved from: http://web.ebscohost.com.ezproxy.waikato.ac.nz/ehost/pdfviewer/pdfviewer?vid=3\&hid=12 \&sid=5c5cde58-5f33-420e-b89c-5e478b27baa0\%40sessionmgr10

Jensen, M. C. (1986). Agency costs of free cash flow, corporate finance, and takeovers. American Economic Review, 76, 323-329.

Jensen, M. C., \&Meckling, W. H. (1976).Theory of the firm: Managerial behavior, agency costs and ownership structure. Journal of Financial Economics, 3(4), 305-360. http://dx.doi.org/10.1016/0304-405X(76)90026-X

Kang, H., Cheng, M., \& Gray, S. J. (2007). Corporate governance and board composition: Diversity and independence of Australian boards. Corporate Governance, 15(2), 194-207. http://dx.doi.org/10.1111/j.1467-8683.2007.00554.x

Klein, A. (1998). Firm performance and board committee structure.Journal of Law and Economics, 41(1), 275-303.

La Porta, R., Lopez-de-Silanes, F., Shleifer, A., \&Vishny, R. (2000). Agency problems and dividend policies around the world.Journal of Finance, 55(1), 1-33.

Lee, K. W., Lev, B., \& Yeo, G. H. H. (2008).Executive pay dispersion, corporate governance and firm performance.Review of Quantitative Finance and Accounting, 30, 315-338. http://dx.doi.org/10.1007/s11156-007-0053-8

Lipton, M., \&Lorsch, J. (1992).A modest proposal for improved corporate board effectiveness.Business Lawyer, 48, 59-77.

Maddala, G. S., \&Lahiri, K. (2009).Introduction to econometrics (4th ed.). West Sussex, England: John Wiley \& Son Ltd.

McConnell, J. J., \&Servaes, H. (1990).Additional evidence on equity ownership and corporate value.Journal of Financial Economics, 27, 595-612. 
Mehran, H. (1995). Executive compensation structure, ownership, and firm performance.Journal of Financial Economics, 38(2), 163-84.

Morck, R., Shleifer, A., \&Vishny, R. W. (1988).Management ownership and market valuation: An empirical analysis. Journal of Financial Economics, 20, 293-315.

Myers, S., (2000).Outside equity. Journal of Finance, 55, 1005-1037. http://dx.doi.org/10.1111/0022-1082.00239

Ning, Y., Davidson, W., \& Wang, J. (2010). Does optimal corporate board size exist? An empirical analysis.Journal of Applied Finance, 20, 57-69.

Opler, T., \& Titman, S. (1993). The determinants of leveraged buyout activity: Free cash flow vs financial distress costs. Journal of Finance, XLVIII, 1985-1999.

Organisation for Economic Co-operation and Development.(2004). Principles of corporate governance. Retrieved from http://www.ifc.org/ifcext/corporategovernance.nsf/AttachmentsByTitle/OECD_Principles_E nglish_2004/\$FILE/OECD+CG+Principles+revised+\%282004\%29.pdf

Reddy, K., Locke, S., \&Scrimgeour, F. (2010). The efficacy of principle-based corporate governance practices and firm financial performance.International Journal of Managerial Finance, 6, 190-216. http://dx.doi.org/10.1108/17439131011056224

Rozeff, M. (1982).Growth, beta and agency costs as determinants of dividend payout ratios.Journal of Financial Research, 3, 249-259.

Setia-Atmaja, L. (2010). Dividend and debt policies of family controlled firms: The impact of board independence. International Journal of Managerial Finance, 6 (2), 128-142. http://dx.doi.org/10.1108/17439131011032059

Shleifer, A., \&Vishny, R. (1986).Large shareholders and corporate control.Journal of Political Economy, 94, 461-488.

Short, H., \&Keasey, K. (1999). Managerial ownership and the performance of firms: Evidence from the UK. Journal of Corporate Finance, 5, 79-101.

Singh, M., \&Davidson,W. A. (2003). Agency costs, ownership structures and corporate governance mechanisms. Journal of Banking and Finance, 27, 793-816. http://dx.doi.org/10.1016/S0378-4266(01)00260-6

Stulz, R. M. (1988). Managerial control of voting rights: financing policies and the market for corporate control. Journal of financial economics,20, 25-54.http://dx.doi.org/10.1016/0304-405X(88)90039-6

Whidbee, D.A. (1997). Board composition and control of shareholder voting rights in the banking industry.Financial Management, 26(4), 27-42.

Yermack, D. (1996). Higher market valuation of companies with a small board of directors. Journal of Financial Economics, 40, 185-211. 